Proc. Estonian Acad. Sci. Geol., 1997, 46, 1, 17-33

\title{
MINERALOGICAL ANALYSIS APPLIED IN PROVENANCE STUDIES OF ESTONIAN NEOLITHIC POTTERY
}

\author{
Volli KALM $^{\mathrm{a}}$, Aivar KRIISKA ${ }^{\mathrm{b}}$, and Jaan ARUVÄLI ${ }^{\mathrm{a}}$
}

a Tartu Ülikooli geoloogia instituut (Institute of Geology, University of Tartu), Vanemuise 46, EE-2400 Tartu, Eesti (Estonia)

b Tartu Ülikooli ajaloo osakond (Department of History, University of Tartu), Lossi 3, EE-2400 Tartu, Eesti (Estonia)

Presented by A. Raukas

Received 10 October 1996, revised 5 November 1996, accepted 24 January 1997

\begin{abstract}
Thirty-nine fragments of pottery from eight Neolithic settlement sites of Estonia were studied by applying different methods of mineralogical analysis. Potsherds from all settlements have the same basic components, but also some specific constituents which most likely will identify the area of manufacture. The compositional features were mainly determined by the character of the local source material and by the composition of temper. The most informative quantitative characteristics of Neolithic pottery are the content of clay minerals, coarse clastics $(>0.5 \mathrm{~mm})$ and quartz (\%), porosity (\%), and the ratio of quartz to feldspars (Q/Fp). Analysis revealed that two out of the 39 potsherds studied had not been manufactured at the place of finding.
\end{abstract}

Key words: Estonia, Neolithic pottery, mineralogy.

\section{INTRODUCTION}

The origin and composition of the source material, as well as archaeological pottery itself, have for a long time been an object of interest for archaeologists. The corresponding research has mostly been descriptive. Usually the methods of investigation are applied, the results of which are not quantitatively measurable, and thus not objectively comparable. However, in the 1990 s quantitative, mainly chemical and geological-mineralogical analyses were used increasingly (Aus, 1992; Kriiska, 1994a, 1994b, 1995b; Kalm, 1996; Kriiska \& Rummi, 1996). The 
aim of this paper was to supplement abundant archaeological data with the results obtained by means of different methods of mineralogical analysis. Solutions were firstly sought to a geo-archaeological problem of determining the peculiarities in pottery composition arising from local geological reasons. Also an attempt was made to use the compositional data for provenance analysis of the raw material used for manufacture of Neolithic pottery.

\section{MATERIAL}

Fragments of pottery from eight Neolithic settlement sites were analysed (Fig. 1).

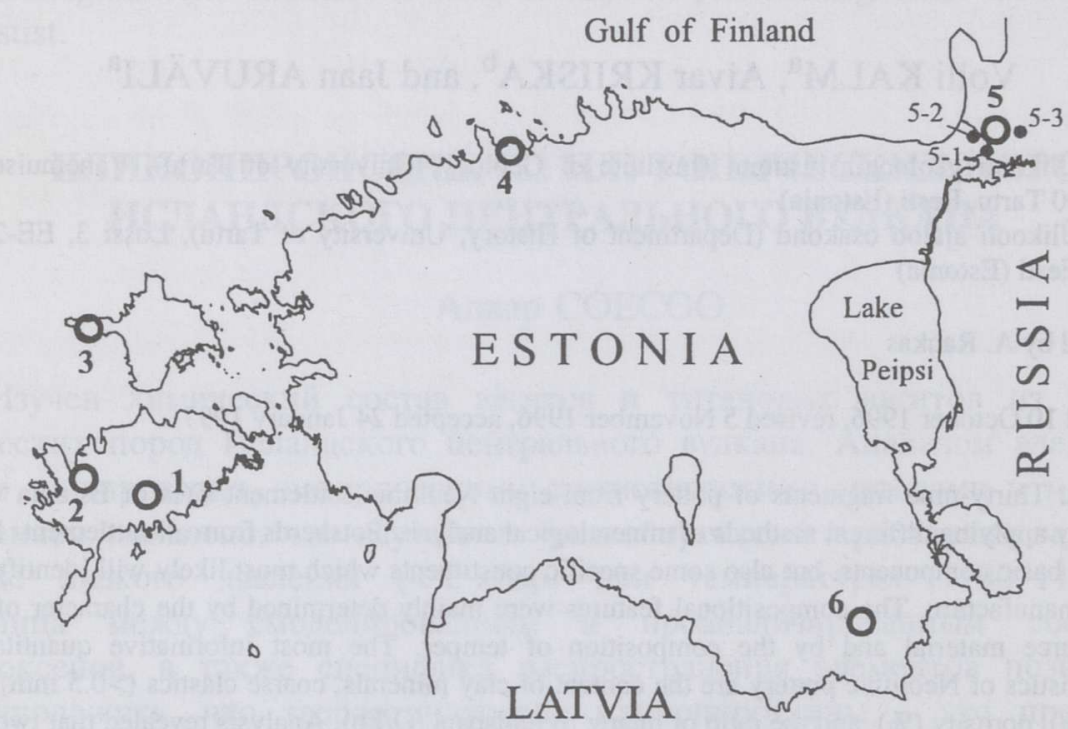

Fig. 1. Neolithic settlement sites mentioned in the text: 1, Kõnnu; 2, Loona; 3, Kõpu I; 4, Kroodi; 5, Narva (5-1, Narva Joaorg; 5-2, Riigiküla I, III; 5-3, Lommi III); 6, Kääpa.

From the Loona site five potsherds, representing the Late Comb Ware, were studied in detail. The settlement site unearthed by A. Kustin and L. Jaanits in 1956-1958 dates from the Late Neolithic. The findings were mostly Late Comb Ware potsherds, but some Late Corded Ware artefacts were recorded as well (Jaanits et al., 1982).

From the Kõnnu site ten pieces of the Pottery of Narva Type were identified. The Kõnnu settlement sites of several Stone Age periods were excavated in the years of 1977-1978. Some pieces of the Early Neolithic pottery were collected (Jaanits, 1979). Although having some specific features, they all belong to the Pottery of Narva Type. 
From the Kõpu I site six potsherds of Narva Type and a burnt clump of clay were thoroughly examined. In 1994 some pieces of Neolithic pottery were found from seven pits in a $34 \mathrm{~m}^{2}$ excavation of the Kõpu I site (Kriiska, 1995a). The total weight of the collected 501 fragments of about 20 earthenware vessels was $520 \mathrm{~g}$. From the same excavation also 44 clumps of clay were found (total weight $115 \mathrm{~g}$ ).

The Kroodi findings are little studied archaeologically. In 1960 L. Jaanits collected from this site 404 potsherds with a total weight of about $700 \mathrm{~g}$. Earlier (Jaanits et al., 1982) this material was considered to be Early Neolithic in age. In this paper we present a rather detailed mineralogical analysis of five fragments of the Pottery of Narva Type from the Kroodi site.

The pottery from the Lommi III, Riigiküla I, III, and Narva Joaorg sites has earlier been described by Gurina (1955, 1961, 1967), Jaanits (Jaanits et al., 1982), and Kriiska (1994a, 1995b). Kriiska (1994a, 1995b) and Kalm (1996) studied the mineral composition and possible temperature of the firing of this material. During the excavations at the multi-layered Stone Age settlement site of Narva Joaorg in 1954, 1957, 1960, and 1962-1964 L. Jaanits collected plenty of pottery. The findings represent all major types of Neolithic Pottery (Jaanits, 1959; Kriiska, 1995b). R. Indreko in 1940 and N. Gurina in 1952 collected abundantly Typical and Late Comb Ware artefacts, and some sherds of the Pottery of Narva Type (Gurina, 1961; Kriiska, 1994b) from the Neolithic settlement site of Lommi III. During the excavations of 1951-1953 at the Riigiküla I settlement site N. Gurina (Gurina, 1967) collected mainly findings of the Typical Comb Ware, and less pottery of the Late Comb Ware and of Narva Type. In 1952, 1953, and 1958 N. Gurina and L. Jaanits excavated the Riigiküla III settlement site and discovered pottery of Narva Type and Late Comb Ware, but less of the Typical Comb Ware (Gurina, 1967; Kriiska, 1994a). This paper presents the results of the analysis of three potsherds from the Lommi III, one from the Riigiküla I, one from the Riigiküla III, and three potsherds from the Narva Joaorg settlement site. The pottery from the Joaorg, Riigiküla I and III, and Lommi III sites at Narva, situated close by each other, are presented under the name "Narva", both in the figures and in the conclusions about different regions.

During the excavations at the Kääpa Neolithic settlement site in 1959-1962 and in 1974, L. Jaanits collected different pottery, which, besides numerous findings of the Pottery of Narva Type, also contains the Typical Comb Ware and Late Corded Ware artefacts (Jaanits, 1976). Three out of the five potsherds analysed represent the Pottery of Narva Type, one belongs to the Typical Comb Ware, and one to the Late Corded Ware.

All together the material analysed (see Table 1) represents four types of pottery: the Pottery of Narva Type (27 samples), the Typical Comb Ware (6 samples), the Late Comb Ware ( 5 samples), and the Late Corded Ware (1 sample). By the way of comparison, a till sample from the close neighbourhood of the Riigiküla settlement site and a piece of burnt clay (till?) from the Kõpu I settlement site were studied. 


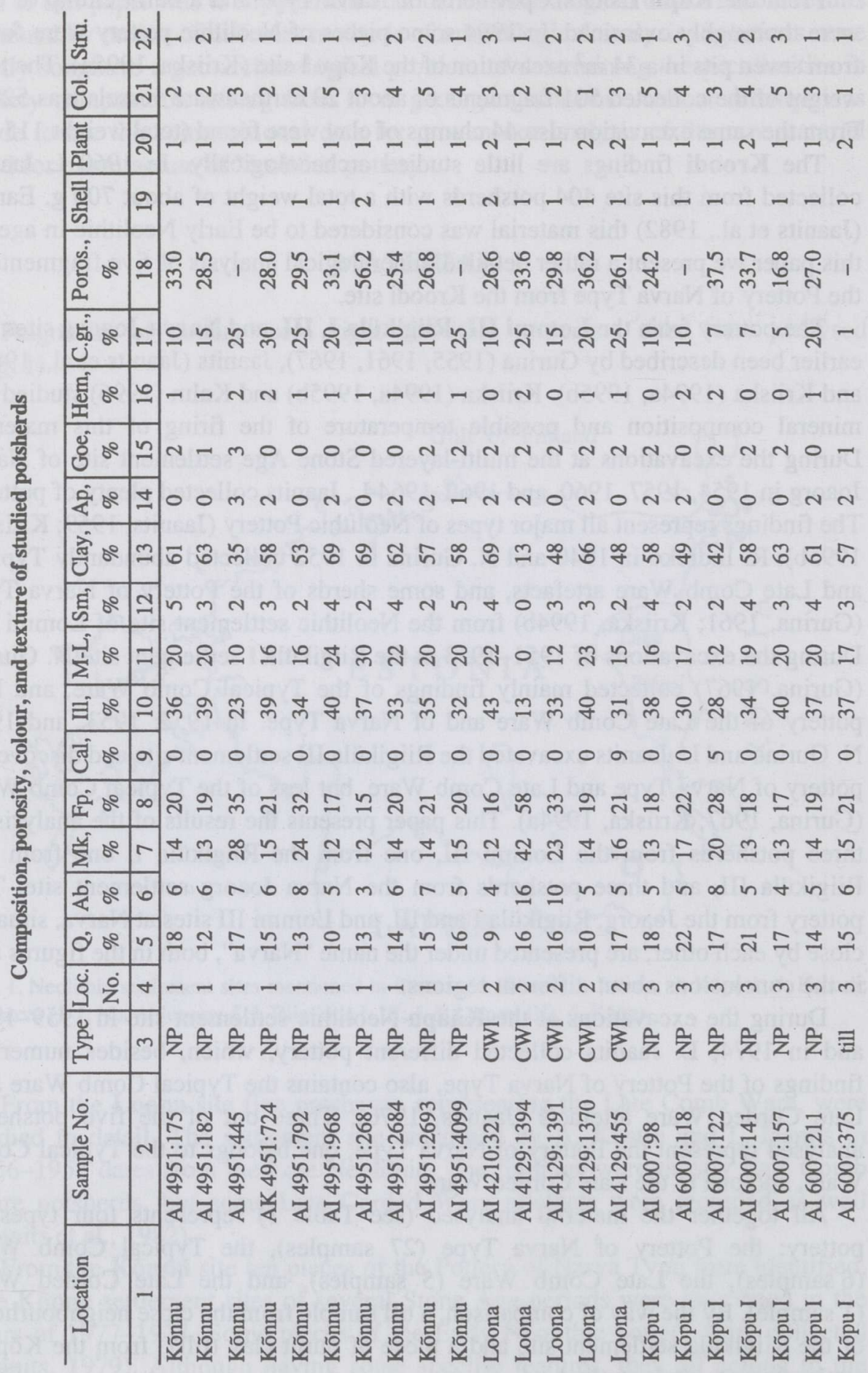



$4 \operatorname{4nmmm-nm-1-1,1m-4mm}$

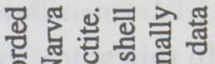
$8 \mathrm{8}$ 政 II

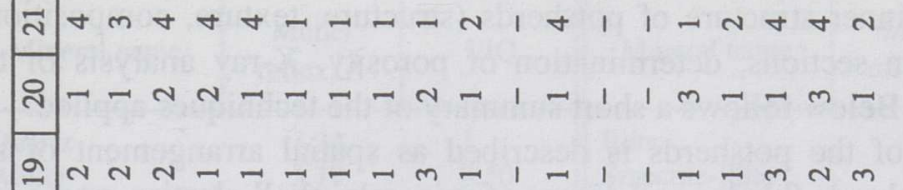

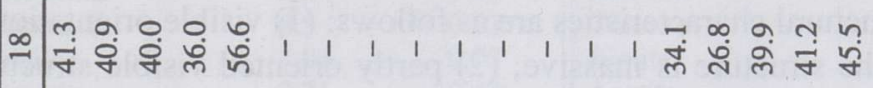

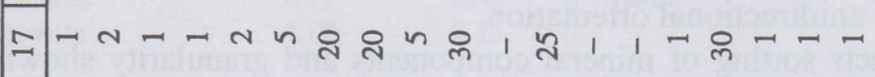

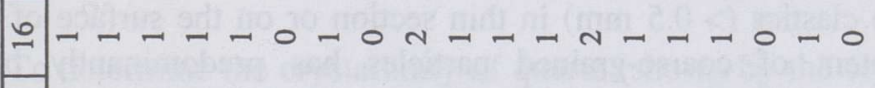
$\pi-4 \rightarrow-700,0,0400,4 n$ h

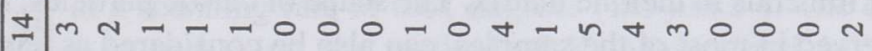

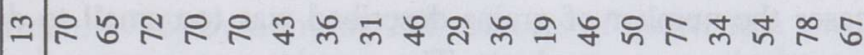

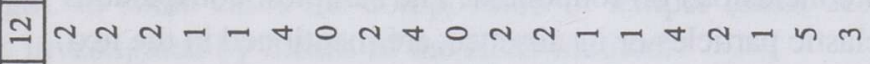

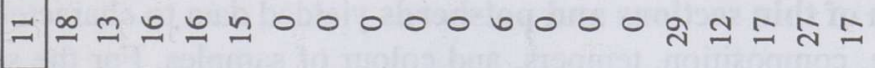
은은ํํำ a $00000000-0000000 \mathrm{~m} 00$

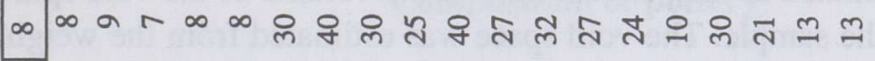

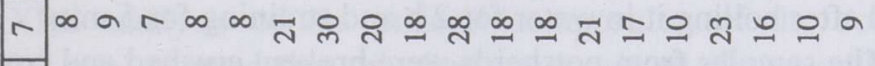

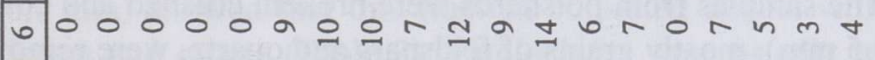
nI $\cong \cong \infty$ ป

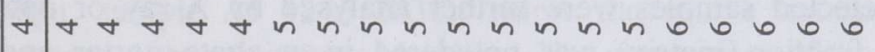

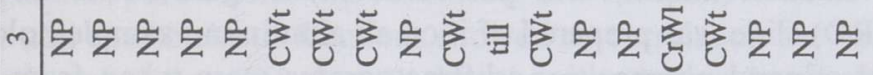

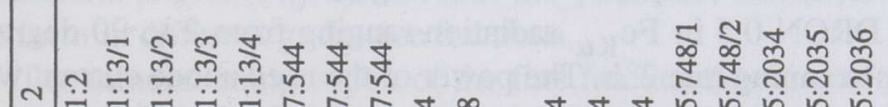

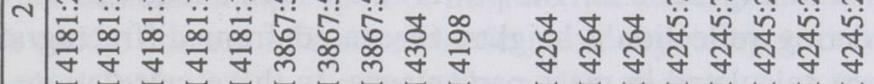

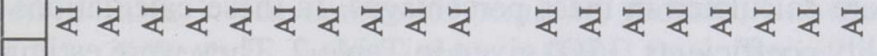
|

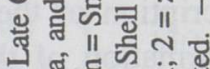

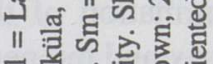
步造造造

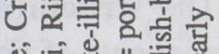

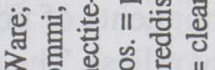

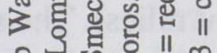
है

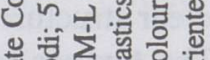
\% II

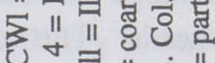
-

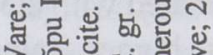
उ है II II 仓् ขึ

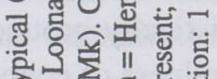
点 1 至 II $\mathrm{N}$ 壱 II 式近望

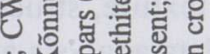
बं क्षे क्वे है II 웡 ॥ II

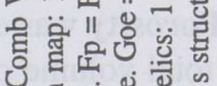
ن य ¿

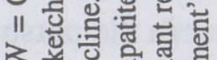

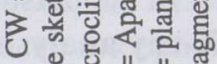
के 독 II II

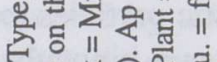

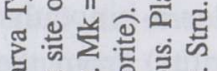
乙 등ㄹ⿺ रु起 II E II

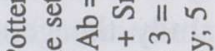

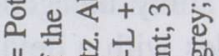
II 岁氙帘苞

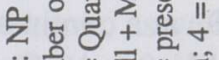
若年目 II 洁

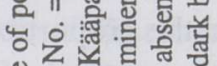
范 II

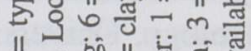
II

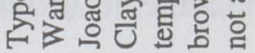


In this study various methods were used: macroscopic description, microscopic description of the inner structure of potsherds (structure, texture, composition), examination of thin sections, determination of porosity, X-ray analysis of the matrix and temper. Below follows a short summary of the techniques applied.

The structure of the potsherds is described as spatial arrangement of the components of potsherds (blades and pieces of minerals, shell clastics, pores and plant relics). The structural characteristics are as follows: (1) visible orientation of particles is absent, the structure is massive; (2) partly oriented visible structure; (3) clear structure of unidirectional orientation.

The texture reflects sorting of mineral components and granularity shown as percentage of coarse clastics $(>0.5 \mathrm{~mm})$ in thin section or on the surface of the potsherds. The content of coarse-grained particles has predominantly been estimated with a $5 \%$ accuracy. One per cent of clastics indicate only the presence of some bigger grains of minerals in the fine matrix. The shape of clastic particles, first of all roundness, observed in most of the samples, can also be considered as part of the texture. In most cases the number of grains described was too small to draw statistically grounded conclusions on roundness. The samples, conspicuous for the roundness of coarse clastic particles or its absence, are mentioned in the text.

The examination of thin sections and potsherds yielded data to characterize the texture, structure, composition, tempers, and colour of samples. For the sake of data analysis and simplicity of presentation the mentioned characteristics were coded, i.e. indicated by numbers (see Table 1).

Porosity was estimated as the per cent ratio of the volume of the void space to the total volume of the sample. The void space was estimated from the weight of water in the potsherd after boiling it in water for $2 \mathrm{~h}$ and straining for $5 \mathrm{~min}$.

$\mathrm{X}$-ray analysis. The samples from potsherds were broken, crushed and coarse clastic particles $(>0.5 \mathrm{~mm})$, mostly grains of feldspars and quartz, were removed under a binocular microscope. The coarse clastic component or tempers (shell detritus) from the selected samples were further analysed by X-ray or optical methods. The finer fraction (matrix) was powdered in an agate mortar and an $\mathrm{X}$-ray diffraction (XRD) slide was prepared of it on an aluminium sample holder. To study the general mineral composition, diffractograms were taken from the slides with a device DRON-0.5 in $\mathrm{Fe}_{\mathrm{K} \alpha}$ radiation ranging from 2 to 90 degrees $(2 \Theta)$ at a continuous scanning rate $2 \%$. The power of the used anode current was $30 \mathrm{kV} \cdot 9 \mathrm{~mA}$. Considering reflection's heights, measured from diffractograms, ratios of minerals were calculated in mass percentages. In these calculations we used the proportionality coefficients (I/IQ) given in Table 2 . They were estimated by the method of artificial mixtures in the XRD Laboratory of the Institute of Geology, University of Tartu. Table 2 also gives the values of model reflexes of the minerals $(\AA)$ for which the proportionality coefficients are valid. 
Minerals determined by the XRD method and their proportionality coefficients (I/IQ)

\begin{tabular}{l|c|c||l|l|l}
\hline Mineral name & $\begin{array}{c}\text { Model } \\
\text { reflex, } \AA\end{array}$ & I/IQ & Mineral name & $\begin{array}{c}\text { Model } \\
\text { reflex, } \AA\end{array}$ & I/IQ \\
\hline Quartz & 3.34 & 1 & Illite & 10.1 & 0.05 \\
Albite & 3.19 & 0.50 & Smectite-illite & 11.5 & 0.06 \\
Microcline & 3.24 & 0.22 & Smectite & 15 & 0.3 \\
Amphibole & 8.5 & 0.22 & Chlorite & 14 & 0.17 \\
Calcite & 3.04 & 0.70 & Biotite & 10.0 & 1 \\
Hematite & 2.71 & 0.42 & Apatite & 2.80 & 0.26 \\
Goethite & 4.18 & 0.25 & & &
\end{tabular}

To determine the crystallinity of quartz (shown by the crystallinity index CI), digital diffractograms were taken from the range 67.3-68.7 degrees $(2 \Theta)$ of $\mathrm{Cu}_{\mathrm{K} \alpha}$ at a scanning rate of 0.01 degrees $(2 \Theta)$ in $5 \mathrm{~s}$. The crystallinity of quartz was determined using the method of K. Murata and M. Norman (Murata \& Norman, 1976) by norming 212 reflexes of quartz to a ten-grade scale of relative height. In some cases the composition of temper (shell detritus, hematite nests) was investigated by means of the XRD method.

\section{RESULTS}

\section{Composition of pottery}

XRD analysis of the mineral composition of the coarse clastic fraction $(>0.5 \mathrm{~mm})$ showed that this fraction consisted almost without an exception of feldspars and quartz (Table 3). Plagioclases were usually represented by a lowtemperature albite and K-feldspars by a maximum microcline. Only in one case (Kääpa, sample AI 4245:2036), where the coarse fraction consisted of shell fragments, pure calcite was identified. The comparison of the results of analysis of fine and coarse clastic fractions showed no correlation between the concentrations of mineral phases (Fig. 2), and thus the quantitative distribution of minerals is not uniform in different grain-size fractions.

The mineral composition of the fine fraction (matrix) of potsherds, as well as data on the content of coarse clastics, porosity, temper, colour, and structure are given in Table 1. The content of hematite, goethite, and apatite is often so small that it is difficult to separate their reflexes from "noise" on the diffractogram. Therefore, the corresponding number indicates rather that their occurrence in the sample is not excluded. Some characteristics (biotite and chlorite contents, crystallinity of quartz) are not very informative and not included in Table 1, but, if necessary, commented on in the text. 
Mineral composition of coarse clastic $(>0.5 \mathrm{~mm})$ temper

\begin{tabular}{l|l|l|c|c|c|c|c}
\hline Location & Sample & Type & $\begin{array}{c}\text { Location } \\
\text { No. }\end{array}$ & $\begin{array}{c}\text { Q, } \\
\%\end{array}$ & $\begin{array}{c}\text { Mk, } \\
\%\end{array}$ & $\begin{array}{c}\text { Ab, } \\
\%\end{array}$ & $\begin{array}{c}\text { Cal, } \\
\%\end{array}$ \\
\hline Loona & AI 4210:321 & CWl & 1 & 36 & 37 & 27 & 0 \\
Kõnnu & AI 4951:2693 & NP & 2 & 35 & 55 & 10 & 0 \\
Kõnnu & AI 4951:4099 & NP & 2 & 20 & 69 & 11 & 0 \\
Kõpu I & AI 6007:98 & NP & 3 & 13 & 78 & 9 & 0 \\
Kõpu I & AI 6007:141 & NP & 3 & 26 & 33 & 41 & 0 \\
Kõpu I & AI 6007:157 & NP & 3 & 53 & 39 & 8 & 0 \\
Kroodi & AI 4181:13/1 & NP & 4 & 25 & 46 & 29 & 0 \\
Kääpa & AI 4245:748/2 & CWt & 6 & 27 & 63 & 10 & 0 \\
Kääpa & AI 4245:2036 & NP & 6 & 4 & 0 & 0 & 96
\end{tabular}

Abbreviations see Table 1.
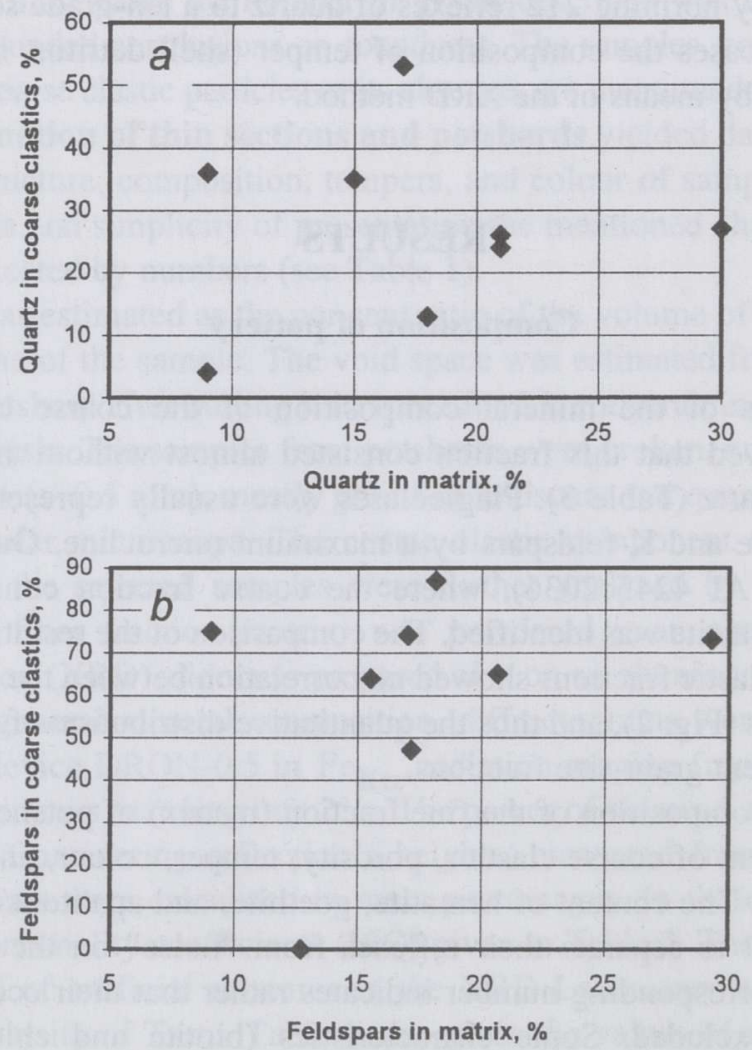

Fig. 2. Relationship between quartz $(a)$ and feldspars $(b)$ in coarse clastic fraction $(>0.5 \mathrm{~mm})$ and fine-grained matrix of Neolithic pottery. 

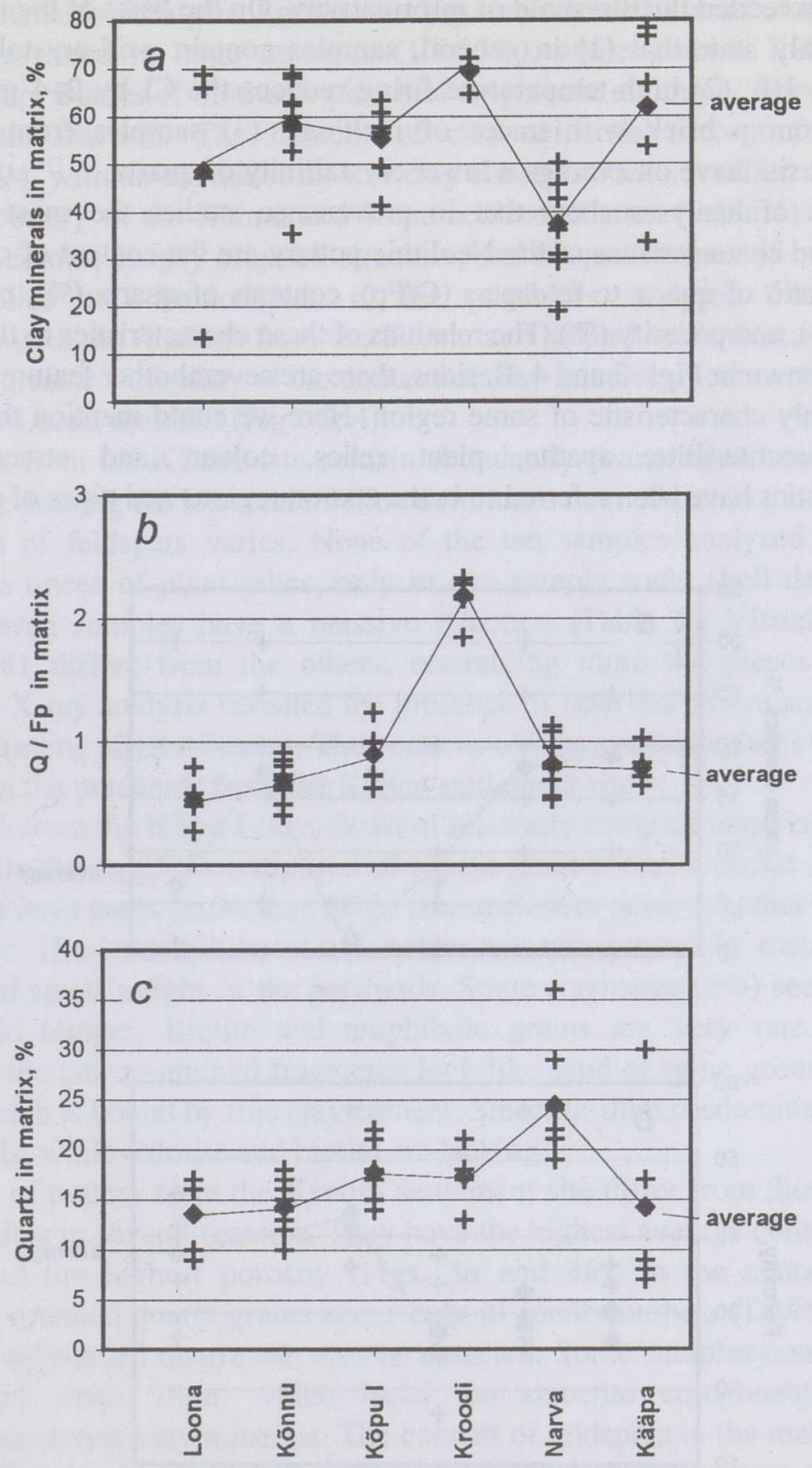

Fig. 3. Dependence of the content of clay minerals $(a), \mathrm{Q} / \mathrm{Fp}$ ratio in matrix $(b)$, and the content of quartz $(c)$ in Neolithic pottery on the place of finding (settlement site). 
The crystallinity of quartz was determined in the fine-grained fraction to characterize the effect of high-temperature firing. Test determinations showed that the error exceeded the threshold of informativity. On the basis of the initial results we can only state that (1) in general, samples contain well-crystallized quartz $(\mathrm{CI}=9$ to 10$)$; (2) high-temperature firing reduces the $\mathrm{CI}$ by $2-4$ grades (a test sample from a brick with traces of melting); (3) samples from the Kroodi settlement site have on average a lower crystallinity of quartz.

Results of analyses show that in provenance studies the most informative quantitative characteristics of the Neolithic pottery are the content of clay minerals $(\%)$, the ratio of quartz to feldspars (Q/Fp), contents of quartz (\%), coarse clastic temper (\%), and porosity (\%). The relations of these characteristics to the settlement sites are shown in Figs. 3 and 4. Besides, there are several other features which may prove highly characteristic of some region. Here we could mention the content of albite, smectite-illite, apatite, plant relics, colour, and structure. These characteristics have been referred to in the text on regions and types of pottery.
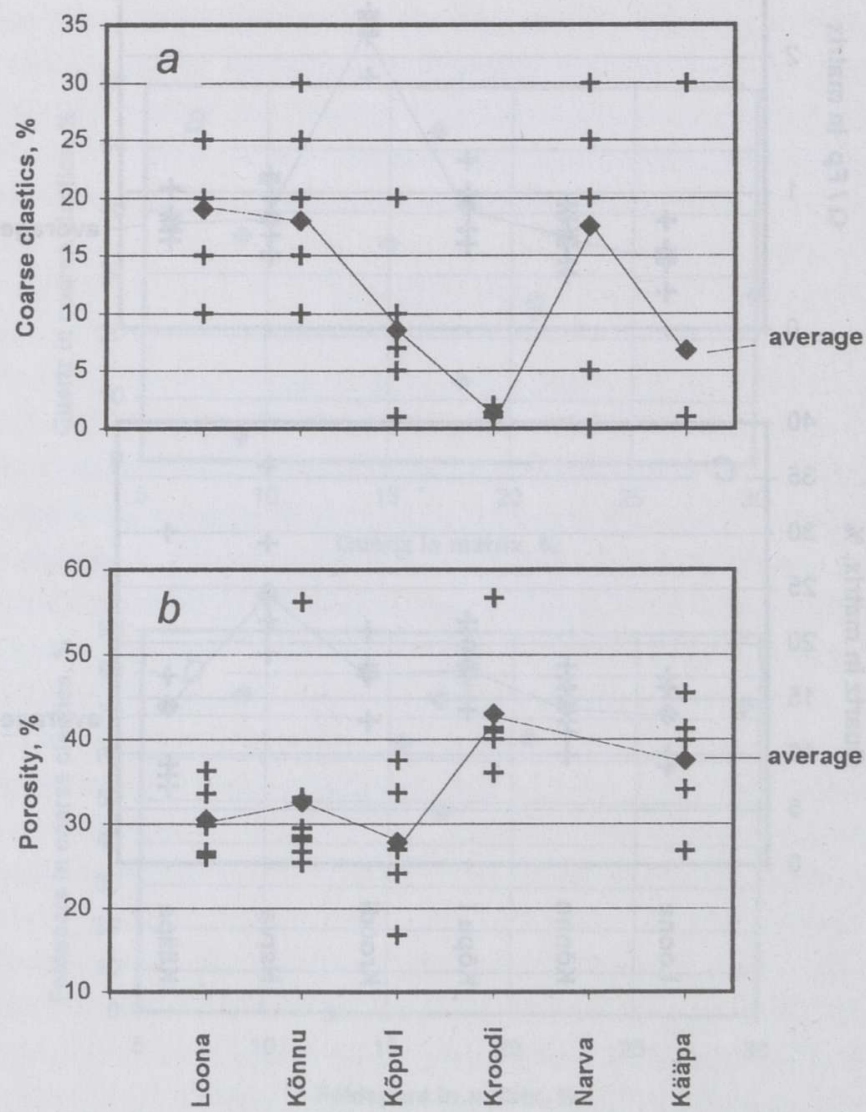

Fig. 4. Dependence of the coarse clastics content $(a)$ and the porosity $(b)$ of pottery on the place of finding (settlement site). 


\section{Characterization of pottery by dwelling sites}

In the potsherds from the Loona site big non-rounded grains of quartz and feldspars are found in large numbers $(10-25 \%)$, while pinkish K-feldspar is almost lacking. Blades of biotite or pieces of amphibole are rarely detected in the coarse clastic fraction. The content of clay minerals (except for sample AI 4129:1394, with an anomalously low clay content) does not differ much from that of the pottery of the Kõnnu and Kõpu settlement sites (Table 1). Brown to dark-brown colour, clearly oriented structure, and frequent traces of burning out of plant relics are characteristic of the potsherds analysed from Loona. Comparison with the findings from the Kõnnu and Kõpu I settlement sites shows a strikingly greater variability of the content of clay minerals, coarse clastics, and quartz in the Loona material (Figs. 3, 4).

Potsherds from the Kõnnu site contain abundantly coarse non-rounded quartz and feldspar. Among the latter microcline dominates over albite. In the matrix the composition of feldspars varies. None of the ten samples analysed contained recognizable traces of plant relics, only in one sample some shell detritus was detected. Seven samples have a massive structure (Table 1). Visually sample AI 4951:2681 differs from the others, resembling more the pieces from the Kroodi site. X-ray analysis revealed the presence of both the biotite and smectite component among phyllosilicates. The contents of iron and amorphous phases are fairly high in the potsherds from the Kõnnu settlement site.

Potsherds from the Kõpu I site consist of relatively compact material, which in turn is mostly (up to $25 \%$ ) composed of coarse-grained non-rounded quartz and feldspars. In most cases (more than $80 \%$ ) coarse clastics occur together with some plant temper. The latter has burnt out, but its use was proved by traces in clay, porosity, and small weight of the potsherds. Some fragments $(5 \%)$ seem to have only organic temper. Biotite and amphibole grains are very rare. Under a microscope the coarse-grained fragments look like sand of some ground granitic material, which is bound by fine clay-cement. Smectite-illite predominates among clay minerals, while chlorite and biotite are lacking.

Samples of pottery from the Kroodi settlement site differ from those of other settlement sites in several features. They have the highest average content of clay minerals and the highest porosity (Figs. $3 a$ and $4 b$ ). In the coarse fraction $(>0.5 \mathrm{~mm}$ ) rounded quartz grains occur only in small numbers (Table 1$)$. In the clay fine non-rounded quartz can also be detected. Some samples contain bright red hematite nests. Illite, which lacks the smectite component, strongly predominates among clay minerals. The content of feldspars in the matrix is low, whereby albite is almost lacking (Table 1). Several findings from the Kroodi settlement site contain apatite in small amounts (AI 4181:2 and AI 4181:13/1). Examination of a large number (about 400) of potsherds from the Kroodi settlement site revealed that the clay used for moulding pottery had mostly $(98.5 \%$ of the cases) been combined with plant temper. The admixture of the latter was 
proved by high porosity of potsherds and traces of plants on breaking surfaces. In rare cases mineral temper had been added to clay. Three fragments contained crushed granite grains and three fragments sand (in one case together with organic temper).

Findings of Neolithic pottery from the Narva localities (Lommi III, Riigiküla I and III, and Narva Joaorg) are remarkable for their hard fine-grained material. There occur also numerous white weathered shell fragments and to a lesser extent some worn coarse clastic grains. The coarse clastic temper contains relatively frequent dark amphibole grains. The amphibole grains have often weathered to biotite. In the mineral composition of the matrix the content of quartz is on average high (Fig. 3). In comparison with other settlement sites the potsherds from the Narva region stand out for their lowest average content of clay minerals (Fig. $3 a$ ), the lack of mixed-layered clay minerals (Table 1, M-L), and a high content of quartz (Fig. 3c).

In two samples from Narva Joaorg (AI 4264) and in one from Riigiküla (AI 4304) apatite was identified in fragments of shell temper. A till sample from Riigiküla, analysed for comparison, contained apatite as well.

Samples from the Kääpa dwelling site show a great variability of the clay content. As a rule, smectite-illite and smectite components predominate among clay minerals (Table 1). Coarse-grained material was found in considerable amounts only in one Comb Ware potsherd (AI 4245:748/2). Sherds of Pottery of Narva Type contain many fine-calcitic fragments of weathered shells or cavities formed as a result of the decomposition of shells. Analysis of the shell temper of a Narva Type potsherd showed the presence of almost pure calcite (Table 3, sample AI 4245:2036). The material analysed from the Kääpa settlement site refers to high variability of most of the compositional features (Figs. 3,4). The structure of the described pieces is in most cases clearly oriented and the colour is zonally brown or grey. Two out of the studied potsherds (AI 4245:748/1 and AI 4245:748/2) from the Kääpa settlement site differ notably from the others. By its substantial (30\%) unworn coarse clastic temper, high quartz content, and relatively low content of clay minerals the potsherd AI 4245:748/2 resembles rather the findings from the Narva area (Table 1).

Judging from several compositional features (absence of albite, low feldspar and coarse clastic contents, high clay content, traces of apatite, oriented structure; see Table 1), the only examined sample of the Corded Ware (AI 4245:748/1) is very similar to the Kroodi potsherds. However, lack of albite and possible occurrence of apatite are not such characteristics, which could depend on the archaeological type of pottery in the Kääpa area. Therefore we may conclude that the pottery analysed must have been brought to the Kääpa site from outside.

The analysis and descriptions performed showed that there are numerous features characteristic of the pottery of some settlement sites, which are either missing in most of the studied samples or negligible. Thus they are not presented in Tables 1 and 3, but are listed below: 
1. relative scarcity of $\mathrm{K}$-feldspars in coarse clastic material - Loona;

2. occurrence of chlorite - Kõnnu, Kääpa;

3. lack of mica and predominance of the smectite component in illite - Kõpu I;

4. red hematite "nests" found in pottery - Kroodi;

5. strong reflex of illite at $10.3-10.5 \AA$ without the smectite component - Kroodi;

6. abundance of mica in pottery - Riigiküla, Lommi III.

\section{DISCUSSION}

The mineral composition of pottery results from several factors: the character of the basic natural material (clayey mass) and temper (coarse clastics, shell detritus, plant relics), processing conditions, and later weathering of material in the cultural layer. The composition of Quaternary deposits of the study area predetermined the constituents of the clayey mass and coarse-grained mineral temper. The Quaternary cover, in turn, depends on the geological structure and development of the area. As expected, the compositions of the till samples analysed from the vicinity of the Kõpu I and Riigiküla settlement sites do not differ much from the composition of pottery recovered from these areas (Table 1). The analyses show that the local geological structure has determined the following regional or mineralogical characteristics of archaeological pottery.

Low contents of feldspars, lack of albite, the quartz/feldspars ratio 1.8-2.3 in the matrix are typical of the potsherds from the Kroodi settlement site, i.e. the pottery manufactured in close vicinity of the North Estonian Klint, at the outcrops of Cambrian silty clay and sandstone. Evidently, under the conditions where the same source material was used to manufacture different archaeological pottery, the composition of the studied samples is similar and cannot convey any information on pottery types.

A low (1-5\%), but definite content of apatite characterizes the artefacts from the Kroodi, Narva Joaorg, and Riigiküla I settlement sites. Most probably apatite originates from the shells of obolid brachiopods which in this region occur only in the sandstone of the Pakerort Formation, Ordovician (Kalm, 1996). Sandstone crops out only at the North Estonian Klint from the Pakri Peninsula in the west to the Narva area and the St. Petersburg region of Russia in the east (Rõomusoks, 1983). All settlement sites, where apatite was identified in potsherds, are located close to the klint. Theoretically apatite of the same origin may get into the composition of pottery through Quaternary glacigenic sediments since till contains the components of the bedrock, once eroded by glacier. The apatite, identified in the till sample from the Riigiküla settlement site (Table 1), confirms this statement. Assuming that apatite entered the pottery with the shell fragments occurring in temper, we may conclude that it can be used for the study of artefacts manufactured using specific technologies. It means that the change in the technology or the appearance of a new type of pottery in the region influence the use of regional mineral deposits. 
The average content of coarse clastics is higher in the Neolithic pottery from Saaremaa (Loona, Kõnnu) and lower in those from mainland Estonia. For this reason the scanty coarse clastic quartz, occurring in the potsherds of the Kroodi and Narva settlement sites, is relatively well rounded. The quartz/feldspars ratio and the role of microcline among feldspars are on average higher in the pottery of islands than of mainland Estonia. Despite this regional peculiarity, a high content of coarse clastics is, first of all, characteristic of the Comb Ware potsherds.

Shell detritus as a temper of clay mass is the most characteristic of the Pottery of Narva Type. In later types of pottery it is rare or entirely lacking. Therefore the presence of shell temper is a feature specifying the archaeological type of pottery. Neolithic settlements were located close to water bodies and shells were found practically in every settlement area. Thus, the presence of detritus cannot be considered as a regional feature of pottery. Still, the study of the composition of shell relics was important, as instead of the usual calcite $\left(\mathrm{CaCO}_{3}\right)$ detritus shell clastics of apatite composition were also found. As mentioned above, the content of apatite refers to a very clear origin of the source material and to the place of manufacture close to the North Estonian Klint.

The conditions of manufacture (temperature of firing and airing conditions, smoothing of the surface of a clay vessel (clay ribbon) before drying) and later weathering in the cultural layer may also have great influence on the composition of pottery. The present paper does not aim to describe the firing temperature and airing conditions at pottery-making. Here we emphasize again that the colour of pottery depends first on the access of oxygen by burning and only secondarily on temperature (Kalm, 1996). Presumably, smoothing of the surface of the clay vessel could be related to the formation of a structure in cross-section, which is of fish-scale-like orientation. Such oriented structure is found in the Pottery of Narva Type as well as in other later types. However, it is common in the potsherds of Narva Type from the Kõpu I, Kroodi, and Kääpa sites, but is very rare in the same type of pottery from Kõnnu (Table 1).

The impact of weathering on the composition of pottery certainly depends on manufacturing conditions as well. Firing temperatures, which are insufficient for irreversible re-crystallization of minerals, allow later weathering, as they destabilize the regular and monolithic structure of minerals.

Based on all the determined features we may conclude that the pottery findings from Loona, Kõnnu, and Kõpu I settlement sites on West Estonian islands are very similar in composition although the Loona settlement site yielded Comb Ware potsherds, but the other two those of the Pottery of Narva Type. The composition of potsherds from the Kõpu I settlement site is very similar to that of a till sample from the neighbourhood (Table 1 ). It is very likely that the pottery under discussion has been manufactured from local material at the settlement site.

Out of the 21 Neolithic potsherds analysed from West Estonian islands only one sample (AI 4210:321) from the Loona settlement site clearly differs from the rest (Table 1). Owing to the low content of albite and coarse clastics and the high 
clay content, the sample resembles most the pottery from Kroodi and Kääpa. The described potsherd is probably not from Kroodi or Kääpa but from Estonian mainland.

As repeatedly pointed out, the Kroodi potsherds differ greatly from the material from other settlements, but are all similar in composition and properties (Table 1, Figs. 3, 4). Therefore, surely all the studied Kroodi pottery has been manufactured at the settlement site.

\section{SUMMARY AND CONCLUSIONS}

At the first stage of compositional analysis, the studied material should be grouped according to porosity, structure, amount of the coarse-grained component, and mineral composition. X-ray analysis is necessary for further specification of the composition and for identification of microcomponents such as shell fragments and single grains. To group the objects according to their mineral compositions, samples of well-averaged compositions or certain fractions have to be examined.

Potsherds found from different places in Estonia have the same basic components, but also some specific features, which allow us to establish the most probable origin of the fragment. These features are mainly determined by the specific properties of the local source material and by the composition of temper, less by differences in manufacturing conditions. The tempers (coarse clastics, shell detritus, plant relics), added to the matrix used for the manufacture of pottery, have different effects on its composition and properties. They have both regional (except plant relics) and typological meaning. Plant relics did not change the mineral composition of pottery, but, by burning out increased the porosity and the content of amorphous phase in the sample.

The analyses performed show that in provenance investigations the most informative quantitative characteristics of the Neolithic Pottery are the contents of clay minerals, the ratio of quartz to feldspars, contents of coarse clastics, quartz, and porosity. The comparison of the results of analysis of fine matrix and coarse clastic fraction revealed no clear positive correlation between the quantities of mineral phases. This proves again that in the manufacture of pottery the coarse clastic component was added to the clay mass and it did not come from the same clayey sediment as the matrix.

The potsherds from the West Estonian islands (Loona, Kõnnu, and Kõpu I) have very similar compositions although they represent different types of pottery. Very likely these artefacts were manufactured on the spot from local material.

The findings from the Kroodi site have similar compositions and qualities. They can be clearly distinguished from the pottery of other settlements and have been manufactured on the spot. The occurrence of well-rounded quartz is characteristic of the matrix of pottery from the Kroodi and Narva regions. 
Among the 39 potsherds studied there are at least two samples (Loona, AI 4210:321 and Kääpa, AI 4245:748/1), which were not manufactured at the place of finding. They were rather imported or traded from other places.

\section{ACKNOWLEDGEMENTS}

This study was supported by a grant from the Commission of the European Communities within the framework of the interdisciplinary PACT project "Environmental History of the Baltic Region".

\section{REFERENCES}

Aus, T. 1992. Tallinna keskaegsed savinõud. Stilus, Eesti Arheoloogiaseltsi Teated, 3, 5-49.

Gurina, N. N. 1955. Novye neoliticheskie pamjatniki Vostochnoj Estonii. In Muistsed asulad ja linnused: Arheoloogiline kogumik I. (Moora, H. \& Jaanits, L., eds.). Tallinn, 153-175 (in Russian).

Gurina, N. N. 1961. Drevnyaya istoriya Severo-Zapada Evropejskoj chasti SSSR. In Materialy $i$ issledovaniya po arkheologii SSSR, 87. Moskva-Leningrad (in Russian).

Gurina, N. N. 1967. Iz istorii drevnikh plemen zapadnykh oblastej SSSR (po materialam Narvskoj ekspeditsii). In Materialy $i$ issledovaniya po arkheologii SSSR, 144. Leningrad (in Russian).

Jaanits, L. 1959. Poseleniya épokhi neolita i rannego metalla v priust'e $r$. Émajygi (Éstonskaya SSR). Tallinn (in Russian).

Jaanits, L. 1976. Ausgrabungen der neolithischen Siedlung in Kääpa. ENSV TA Toimetised. Ühiskonnateadused, 25, 1, 45-48 (in Russian).

Jaanits, L. 1979. Die neolithische Siedlung Kõnnu auf der Insel Saaremaa. ENSV TA Toimetised. Ühiskonnateadused, 28, 4, 363-367.

Jaanits, L., Laul, S., Lõugas, V. \& Tõnisson, E. 1982. Eesti esiajalugu. Eesti Raamat, Tallinn.

Kalm, V. 1996. X-ray diffraction analysis of Neolithic ceramics: Examples from the Narva area, north-east Estonia. In Environmental and Cultural History of Coastal Estonia: Recent Advances. (Miller, U., Saarse, L. \& Hicks, S., eds.). PACT, 51, 385-398.

Kriiska, A. 1994a. Keraamika uurimise võimalikkusest I. Stilus, Eesti Arheoloogiaseltsi Teated, 5, 94-103.

Kriiska, A. 1994b. Narva jõe alamjooksu ala neoliitiline keraamika. Magistritöö. Käsikiri Tartu Ülikooli ajaloo osakonnas.

Kriiska, A. 1995a. Archäologische Ausgrabungen auf dem Standort der ehemaligen Steinzeitsiedlung Kõpu I (Ristipõllu). Proc. Estonian Acad. Sci. Humanities and Social Sciences, 44, 4, 410-416.

Kriiska, A. 1995b. Narva jõe alamjooksu ala neoliitiline keraamika. In Muinasaja teadus, 3. Eesti arheoloogia historiograafilisi, teoreetilisi ja kultuuriajaloolisi aspekte. (Jaanits, L. \& Lang, V., eds.). Agu, Tallinn, 54-115.

Kriiska, A. \& Rummi, P. 1996. Loodusteaduslike meetodite rakendamisest arheoloogilise keraamika uurimisel. Keraamika uurimise võimalikkusest II. Stilus, Eesti Arheoloogiaseltsi Teated, 6, 21-29.

Murata, K. J. \& Norman, M. B. 1976. An index of crystallinity for quartz. Am. J. Sci., 276, 11201130 .

Rõõmusoks, A. 1983. Eesti aluspõhja geoloogia. Valgus, Tallinn. 


\title{
MINERALOOGILINE ANALÜÜS EESTI NEOLIITILISE KERAAMIKA PÄRITOLU UURINGUTES
}

\section{Volli KALM, Aivar KRIISKA ja Jaan ARUVÄLI}

Kaheksa asulakoha 39 neoliitilise savinõukillu koostise uurimisel selgus, et need kõik sisaldavad ühesuguseid põhikomponente - savimineraalidest, kvartsist ja päevakividest koosnevat peeneteralist põhimassi ning savi lisandina kasutatud jämepurdset kvartsi, päevakive, karbidetriiti ja taimejäänuseid. Lisaks nimetatud komponentide olemasolule on kindlaks tehtud keraamika koostise niisugused tunnused, mis suure tõenäosusega võimaldavad määrata savinõu valmistamise koha. Eesti oludes sobivad selleks kõige paremini järgmised kvantitatiivselt mõõdetavad näitajad: savimineraalide, kvartsi ja jämepurru $(>0,5 \mathrm{~mm})$ sisaldus (\%) ning kvartsi ja päevakivide suhe (Q/Fp) põhimassis, samuti põhimassi poorsus (\%). Tuginedes koostise analüüsile on järeldatud, et enamik uuritud keraamikast on valmistatud leiu(asula)kohas või selle vahetus läheduses ning ainult kaks savinõu uuritud 39-st ei ole valmistatud nende leiukohas, vaid on toodud sinna mujalt.

\section{МИНЕРАЛЬНЫЙ АНАЛИЗ В ИССЛЕДОВАНИИ ПРОИСХОЖЛЕНИЯ НЕОЛИТИЧЕСКОЙ КЕРАМИКИ ЭСТОНИИ}

\author{
Волли КАЛМ, Айвар КРИЙСКА и Яан АРУВЯЛИ
}

Изучен минеральный состав 39 образцов неолитической керамики из восьми поселений Эстонии. Установлено, что тестообразующие компоненты глины всех образцов одинаковы. Основная часть глиняного теста мелкозернистая, состоит из глинистых минералов, кварца и полевых шпатов; в качестве добавок присутствуют крупнозернистые фракции (>0,5 мм) кварца и полевых шпатов, а также ракушечный детрит и растительные добавки. Кроме того, определены процентные содержания компонентов, пористость и соотношение кварца и полевых шпатов. На основании полученных качественных и количественных признаков сделан вывод, что из общего числа изученных образцов 37 изготовлены в местах их нахождения и только два образца имеют импортное происхождение. 